\title{
Analisis Distribusi Intensitas RGB Citra Digital untuk Klasifikasi Kualitas Biji Jagung menggunakan Jaringan Syaraf Tiruan
}

\author{
M. Arief Bustomi* dan Ahmad Zaki Dzulfikar \\ Jurusan Fisika, Fakultas Matematika dan Ilmu Pengetahuan Alam, \\ Institut Teknologi Sepuluh Nopember (ITS), Jl. Arief Rahman Hakim, Surabaya 60111
}

\begin{abstract}
Intisari
Telah dilakukan penelitian dan pembuatan program komputer berbasis jaringan syaraf tiruan backpropagation yang bertujuan untuk mengklasifikasikan kualitas biji jagung berdasarkan pada pola distribusi intensitas RGB citra digital biji jagung tersebut. Dalam penelitian ini, kualitas biji jagung terklasifikasi dalam 4 kelompok, yaitu biji busuk, biji berjamur, biji normal, dan biji rusak. Jumlah sampel yang digunakan adalah 120 sampel untuk pelatihan dan 80 sampel untuk pengujian. Urutan tahapan penelitian adalah sebagai berikut: filterisasi citra digital dengan median filter, ekualisasi dengan histogram adaptif, ekstraksi indeks warna RGB untuk ketiga intensitas warna RGB, dan penghitungan mean dan standard deviasi untuk masing-masing indeks warna RGB tersebut. Selanjutnya dari pola mean dan standard deviasi ketiga indeks warna RGB dapat digunakan untuk mengenali kualitas biji jagung menggunakan metode jaringan syaraf tiruan backpropagation. Dalam penelitian ini, jaringan syaraf menggunakan fungsi aktivasi log-sigmoid dan dapat mengenali pola secara optimal bila digunakan 1500 iterasi, 500 neuron, 4 hidden layer, 4 output layer, dan laju pembelajaran 0,01. Hasil penelitian memperlihatkan bahwa jaringan syaraf tiruan yang telah dibuat ternyata mempunyai tingkat akurasi rata-rata sebesar $100 \%$ pada proses pelatihan dan sebesar $73,75 \%$ pada proses pengujian.
\end{abstract}

\begin{abstract}
The research and manufacture of computer programs based backpropagation neural network which aims to classify the quality of corn seeds based on RGB intensity distribution pattern of digital image of the corn seeds have been done. In this research, the quality of corn seeds classified into 4 groups, namely rotten seeds, moldy seeds, normal seeds and damaged seeds. The number of samples used is 120 samples for training and 80 samples for testing. The order of the stages of the research are as follows : filtering the digital image with the median filter, equalization with adaptive histogram, extracting RGB color index for the three RGB color intensity, and calculating the mean and standard deviation for each of the RGB color index. Furthermore, from the pattern of the mean and standard deviation of the three RGB color index can be used to identify the quality of corn seeds using backpropagation neural network method. In this research, the neural network using the log-sigmoid activation function and can recognize patterns optimally when used 1500 iterations, 500 neurons, 4 hidden layer, the output layer 4 , and a learning rate of 0.01 . The results showed that the neural network which has been made apparently has an average accuracy rate of $100 \%$ on the training process and amounted to $73.75 \%$ on the testing process.
\end{abstract}

KATA KUNCI: Corn seeds quality, RGB color index, The mean and standard deviation pattern, Backpropagation neural network

\section{PENDAHULUAN}

Indonesia merupakan negara agraris karena sebagai besar masyarakatnya mengandalkan hidupnya dari sektor pertanian. Namun dalam beberapa tahun teakhir, lahan pertanian semakin menyempit karena pertumbuhan industri yang sangat pesat sehingga mengurangi produktivitas hasil pertanian dan ketahanan pangan nasional. Salah satu bahan pangan yang ter-

*E-MAIL: ancam produktivitasnya adalah jagung (Zeamays $L$ ). Jagung memiliki nilai strategis karena jagung juga merupakan sumber pangan pokok di beberapa daerah Indonesia.

Selain meningkatkan produktivitas jagung, hal lain yang juga harus diperhatikan adalah peningkatan kualitas produk jagung tersebut. Hal tersebut perlu dilakukan agar komoditas jagung memiliki keunggulan kompetitif. Namun kenyataannya, permasalahan kualitas pada biji-bijian khususnya jagung sampai saat ini masih menjadi sebuah persoalan. Tingginya tingkat kerusakan biasanya disebabkan oleh cara-cara penanganan yang kurang baik. Sebagai contoh adalah pada proses perontokan dengan mesin, sejumlah biji jagung terkelupas kulitnya sehingga akan memudahkan jamur untuk tumbuh se- 
TABEL I: Definisi kualitas fisik biji jagung.

\begin{tabular}{lll}
\hline \hline Kualitas & Definisi \\
\hline 1 & Biji Busuk & $\begin{array}{l}\text { Biji jagung yang sudah mati sehingga kandungan } \\
\text { gizinya sudah hampir tidak ada dan berwarna } \\
\text { kehitaman }\end{array}$ \\
\hline 2 & Biji Berjamur & $\begin{array}{l}\text { Biji jagung yang sudah terserang jamur berwarna } \\
\text { coklat kekuningan }\end{array}$ \\
\hline 3 & Biji Normal & $\begin{array}{l}\text { Biji jagung utuh/normal tanpa adanya cacat, } \\
\text { pecah, atau jamur berwarna kuning segar }\end{array}$ \\
\hline 4 & Biji Rusak & $\begin{array}{l}\text { Biji jagung yang telah terserang organisme, } \\
\text { serangga, atau hama berwarna kuning pucat dan } \\
\text { pecah-pecah }\end{array}$ \\
\hline \hline
\end{tabular}

cara cepat terutama dari jenis Aspergillus yang berpotensi menghasilkan aflatoksin [1]. Selama ini evaluasi kualitas biji jagung dalam proses pengklasifikasian kualitas masih dilakukan secara manual melalui pengamatan visual. Evaluasi kualitas dengan cara ini memiliki beberapa kelemahan, antara lain membutuhkan waktu lama dan menghasilkan produk dengan kualitas yang tidak konsisten. Ketidakkonsistenan ini disebabkan keterbatasan visual manusia, kelelahan dan adanya perbedaan persepsi tentang kualitas oleh masingmasing pengamat [1].

Pengolahan citra merupakan alternatif untuk mengatasi masalah tersebut. Cara ini memiliki kemampuan yang lebih peka karena dilengkapi sensor elektro-optik yang bisa dipastikan akan lebih tepat dan objektif dibandingkan dengan cara visual yang bersifat subjektif dan dipengaruhi oleh kondisi psikis pengamatnya. Kedepan, pengolahan citra ini diharapkan akan menjadi salah satu pilihan dalam pengujian kualitas fisik biji jagung tanpa merusak sampel (objek). Penggunakan teknologi ini, kualitas fisik biji jagung dapat ditentukan dengan cepat, murah, dengan tingkat ketelitian yang dapat dipercaya. Penggunaan teknologi pengolahan citra untuk mengidentifikasi kualitas fisik biji jagung dapat memberikan tingkat ketepatan sampai dengan 95\% [2].

Artikel ini akan memaparkan hasil penelitian untuk pengklasifikasian kualitasi biji jagung dengan memanfaatkan perbedaan indeks warna RGB dari berbagai kualitas biji jagung. Tujuan dari penelitian adalah untuk menghasilkan suatu sistem perangkat lunak berbasis jaringan syaraf tiruan backpropagation untuk mengklasifikasikan biji jagung ke dalam empat macam kualitas biji jagung, yaitu biji jagung busuk, biji jagung berjamur, biji jagung normal, atau biji jagung rusak, serta menganalisis bagaimana performansi sistem perangkat lunak yang telah dibuat tersebut.

\section{DASAR TEORI}

\section{Kualitas Biji Jagung}

Definisi kualitas fisik biji jagung dan penampakan visualnya diperlihatkan pada Gambar 1 dan Tabel I.

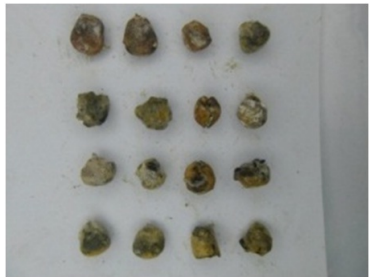

(a) Biji Busuk

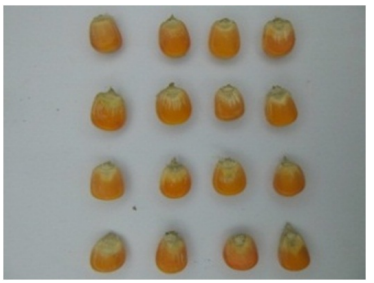

(c) Biji Normal

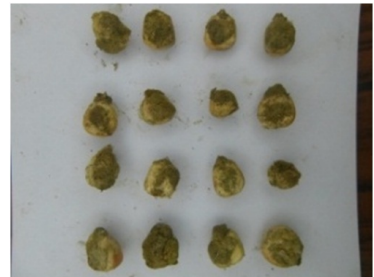

(b) Biji Berjamur

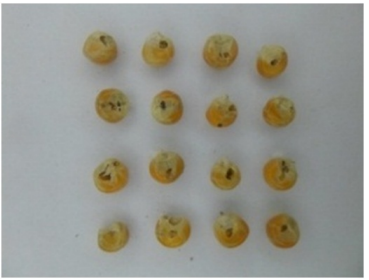

(d) Biji Rusak
Gambar 1: Berbagai kualitas biji jagung.

\section{Pengolahan Citra}

Pengolahan citra merupakan suatu cara untuk mengolah citra sehingga dihasilkan citra yang kualitasnya lebih baik sesuai dengan keinginan. Operasi-operasi yang diterapkan dalam pengolahan citra dapat bertujuan antara lain untuk keperluan perbaikan citra, modifikasi citra, pengelompokan citra, penggabungan citra [3].

\section{Jaringan Syaraf Tiruan Backpropagation}

Jaringan Saraf Tiruan (JST) merupakan suatu metode komputasi yang mencoba untuk meniru cara kerja jaringan syaraf otak manusia yang merupakan sebuah sistem jaringan syaraf mempunyai kemampuan menyimpan, mengenal dan menirukan sesuatu bila kepadanya diberikan sebuah proses pembelajaran. Metode komputasi jaringan syaraf tiruan, mencoba mengimplementasikan kerja jaringan syaraf dalam komputasi, dimana akan ada proses pembelajaran terlebih dahulu, sebelum sistem komputasi tersebut digunakan. Backpropagation merupakan algoritma pembelajaran yang terawasi dan biasanya digunakan oleh perceptron dengan banyak lapisan untuk mengubah bobot-bobot yang terhubung dengan neuronneuron yang ada pada lapisan tersembunyinya (hidden layer) $[3,4]$.

\section{METODOLOGI PENELITIAN}

Bahan utama yang digunakan dalam penelitian ini adalah 200 sampel biji jagung dengan 4 macam kualitas, yaitu biji busuk, biji berjamur, biji normal, dan biji rusak. Dari 200 sampel tersebut, 120 sampel untuk keperluan pelatihan jaringan syaraf dan 80 sampel untuk keperluan pengujian kinerja jaringan syaraf tiruan. Peralatan yang digunakan dalam penelitin ini adalah box sampel sebagai alas yang terbuat dari papan berukuran $30 \mathrm{~cm} \times 30 \mathrm{~cm}$, sebuah magnifier lamp sebagai lampu sekaligus pembesar sampel, sebuah kamera digital 


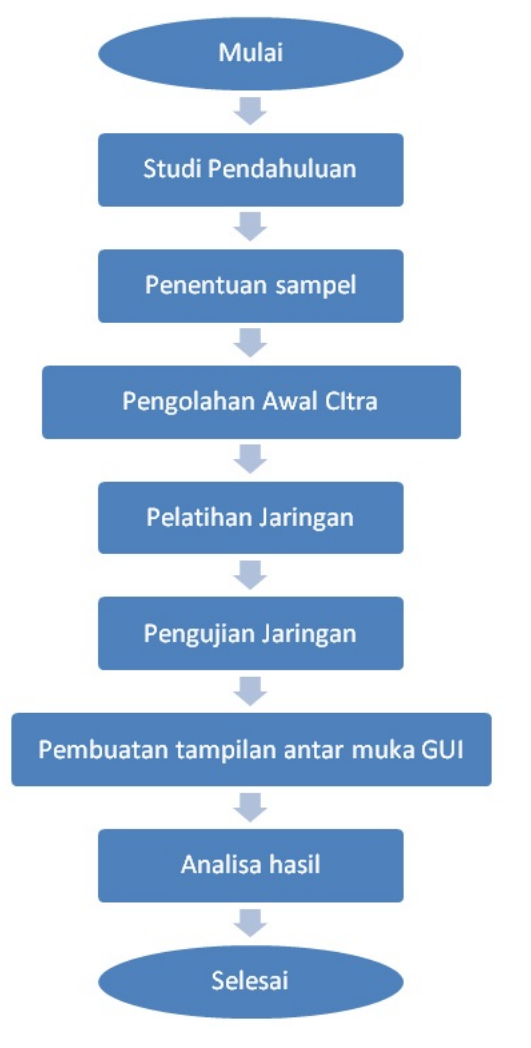

Gambar 2: Diagram alir penelitian.

dengan merek Samsung DV100 dengan jarak $10 \mathrm{~cm}$ dan resolusi 16 megapixel, dan sebuah laptop berjenis ASUS K43E. Perangkat lunak yang digunakan dalam penelitian ini adalah Matlab R2008a. Proses lengkap penelitian ini dapat dilihat pada Gambar 2.

\section{Pengolahan Awal Citra Backpropagation}

Pengolahan citra digital merupakan proses pengolahan dan analisis citra yang banyak melibatkan persepsi visual. Proses ini mempunyai data masukan dan data keluaran yang berbentuk citra [5]. Citra digital dapat diperoleh secara otomatis dari sistem penangkap citra digital yang melakukan penjelajahan citra dan membentuk suatu matriks, dimana elemen-elemen matrik tersebut menyatakan nilai intensitas cahaya pada suatu himpunan diskrit dari titik-titik citra. Perhitungan parameter indeks warna R, G, dan B diperoleh dari tiap-tiap pixel pada citra. Pembangkitan karakteristrik dari citra dapat juga didasarkan atas nilai indeks warna RGB (Red, Green, Blue) [6]. Proses pengolahan awal citra dalam penelitian ini disajikan pada Gambar 3.

Proses pertama adalah pengambilan citra masing-masing sampel biji jagung yang dilakukan dengan menggunakan magnifier lamp dan kamera digital. Kemudian dilakukan cropping untuk mendapatkan sebagian kecil dari sampel tersebut. Langkah selanjutnya adalah mengekstraksi nilai indeks warna RGB untuk tiap-tiap sampel biji jagung.

$$
I_{\text {Red }}=\frac{R}{R+G+B}
$$

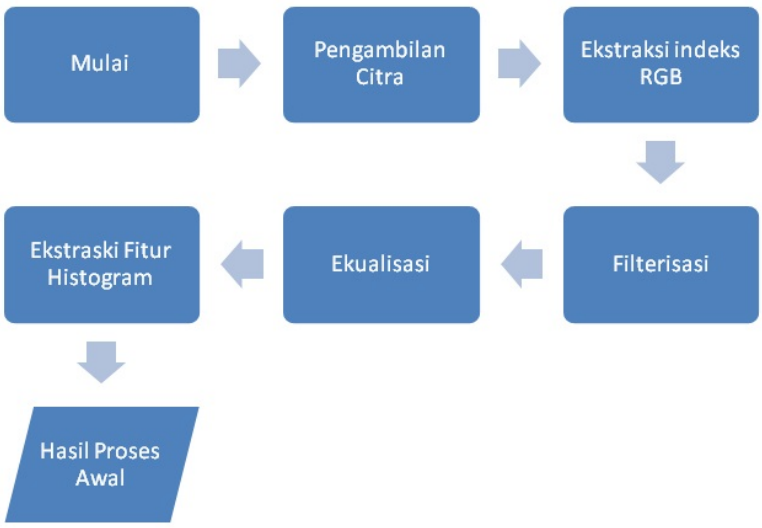

Gambar 3: Proses pengolahan awal citra.

Proses berikutnya adalah filtering yang bertujuan untuk menghilangkan noise pada citra. Filter yang digunakan adalah median filter. Median filter termasuk filter nonlinear, dimana filter ini menghitung nilai dari setiap pixel yang baru, yaitu nilai pixel pusat koordinat sliding window dengan nilai tengah dari pixel di dalam window [7]. Secara matematis, median filter dinyatakan sebagai berikut:

$$
O(i, j)=\operatorname{median}\{u(i+k-1, j+\ell-1)\}
$$

Setelah citra terfilter, berikutnya adalah proses ekualisasi menggunakan adaptif histogram yang bertujuan untuk menghasilkan histogram citra yang seragam. Pada dasarnya ekualisasi histogram adaptif sama dengan ekualisasi histogram biasa, hanya saja pada ekualisasi histogram adaptif citra dibagi menjadi beberapa blok (sub-image) dengan ukuran $n \times n$. Kemudian pada setiap blok dilakukan proses ekualisasi histogram. Distribusi ulang terhadap histogram awal dilakukan dengan memetakan setiap nilai pixel pada histogram awal menjadi nilai pixel baru [5]. Secara matematis, ekualisasi adaptif histogram dinyatakan sebagai berikut:

$$
n(g)=\max \left(0, \text { round }\left[(L-1) * \frac{c(g)}{N}\right]-1\right)
$$

Selanjutnya adalah ekstraksi fitur histogram yang merupakan metode pengambilan ciri berdasarkan pada karakteristik histogram citra, dimana histogram menunjukkan probabilitas kemunculan nilai tingkat intensitas pixel pada suatu citra. Jika x menyatakan tingkat keabuan pada suatu citra, maka probabilitas $\mathrm{P}(\mathrm{x})$ dinyatakan sebagai berikut [5]:

$$
P(x)=\frac{\text { jumlah titik dg tingkat keabuan } \mathrm{x}}{\text { jumlah total titik pada citra }}
$$

dengan $\mathrm{x}=0,1,2,3, \mathrm{~L}-1$

Ekstraksi fitur histogram yang digunakan dalam penelitian ini hanya ada 2, yaitu :

1. Mean $(\mu)$

Mean merupakan ukuran disperse dari suatu citra

$$
\mu=\sum_{n} f_{n} p\left(f_{n}\right)
$$




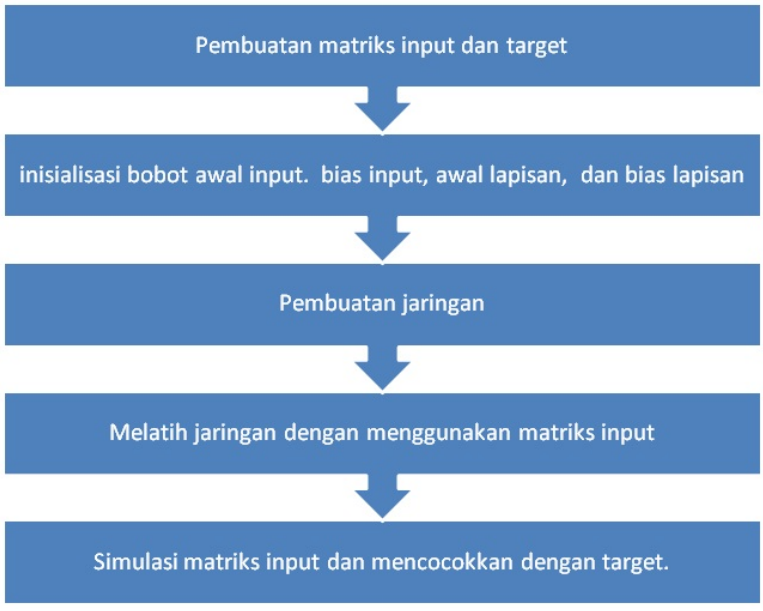

Gambar 4: Proses pelatihan dan pengujian.

Dengan $f_{n}$ merupakan suatu nilai intensitas keabuan, sementara $\mathrm{p}\left(\mathrm{f}_{n}\right)$ menunjukkan nilai histogramnya (probabilitas kemunculan intensitas tersebut pada citra)

2. Standar Deviasi $(\sigma)$

Standar Deviasi merupakan cerminan dari rata-rata penyimpangan data dari mean.

$$
\sigma=\sum_{n}\left|f_{n}-\mu\right|\left(f_{n}\right)
$$

Kedua ekstraksi ini dilakukan untuk masing-masing indeks warna RGB setiap citra, sehingga didapatkan 6 data untuk setiap citra. Hasil ekstraksi ini disimpan dalam database dan dijadikan sebagai parameter utama dalam pengklasifikasian kualitas biji jagung.

\section{Pelatihan dan Pengujian Jaringan Backpropagation}

Proses pelatihan dan pengujian dilakukan dengan menggunakan jaringan syaraf tiruan metode backpropagation. Proses pelatihan berguna untuk melatih sistem untuk mengenali citra serta untuk mendapatkan bobot. Bobot ini yang akan digunakan sebagai masukan dalam proses pengujian. Gambar 4 memperlihatkan diagram alir proses tersebut.

\section{Pembuatan GUI (Graphical User Interface) Backpropagation}

Setelah semua proses pengolahan citra, pelatihan serta pengujian jaringan syaraf tiruan dilakukan, proses berikutnya adalah pembuatan tampilan antarmuka GUI. Tampilan ini berfungsi untuk memudahkan pengguna dalam mengoperasikan sistem perangkat lunak Matlab. Menu yang ditampilkan antara lain adalah:

\section{Pengolahan awal citra latih \\ 2. Pengolahan awal citra uji}

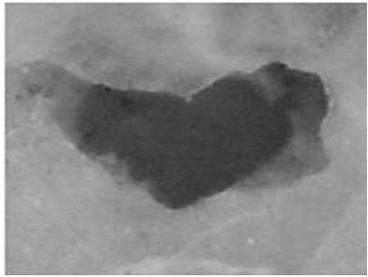

(a) Ekstraksi R

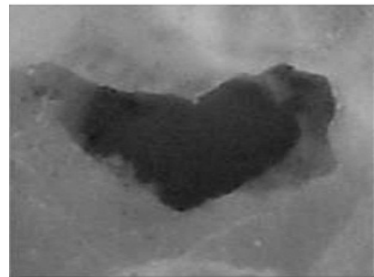

(b) Ekstraksi G

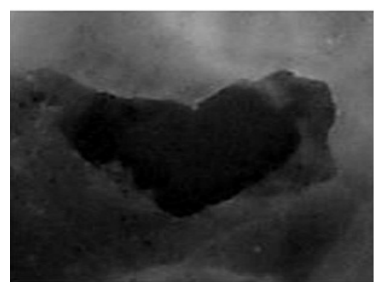

(c) Ekstraksi B

Gambar 5: Citra latih no. 120.

TABEL II: Nilai indeks bias citra latih Ke-120.

\begin{tabular}{lcc}
\hline \hline Warna & \multicolumn{2}{c}{ Nilai Indeks Warna } \\
& Minimum & Maksimum \\
\hline Red & 61 & 165 \\
Green & 34 & 150 \\
Blue & 0 & 112 \\
\hline
\end{tabular}

3. Pelatihan

4. Pengujian satu data

5. Pengujian seluruh data

\section{HASIL DAN PEMBAHASAN}

\section{Ekstraksi Indeks Warna RGB}

Seperti diketahui bahwa tiap citra yang berwarna memiliki nilai indeks warna RGB yang bermacam-macam. Perbedaan prosentase indeks RGB membuat suatu citra menjadi berwarna merah, hijau, biru, kuning dan sebagainya. Semakin tinggi indeks warnanya, maka citra tersebut akan semakin terang. Begitu pula sebaliknya, semakin kecil nila indeks warnanya, maka citra akan semakin gelap. Dalam penelitian ini, ketiga nilai indeks tersebut akan dipisahkan dan akan dijadikan parameter dalam melakukan klasifikasi. Tampak pada Gambar 5 citra latih ke 120 bahwa ekstraksi R lebih terang dibanding $\mathrm{G}$ dan $\mathrm{B}$ yang berarti nilai indeks RGB nya tinggi. Berdasar data dari workspace Matlab, didapatkan data seperti pada Tabel II.

\section{Filterisasi}

Filterisasi yang digunakan dalam penelitian ini adalah median filter. Median filter yang digunakan memiliki blok di- 


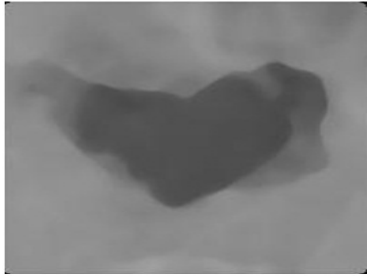

(a) Ekstraksi R

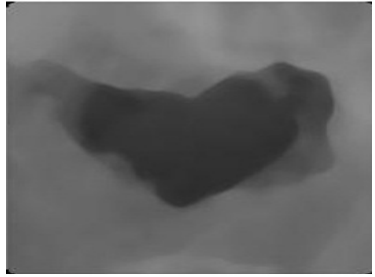

(b) Ekstraksi G

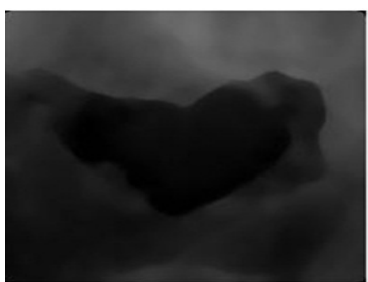

(c) Ekstraksi B

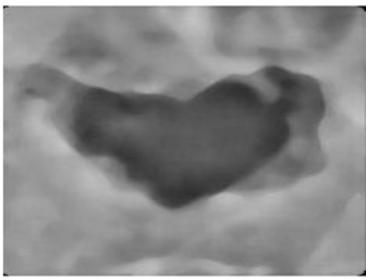

(a) Ekstraksi R

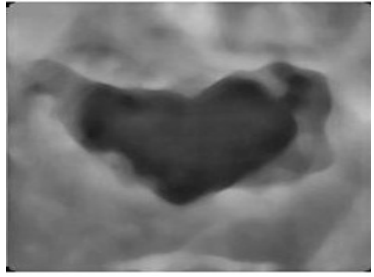

(b) Ekstraksi G

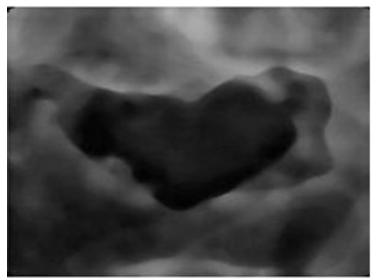

(c) Ekstraksi B

Gambar 7: Hasil ekualisasi citra latih No. 120. mensi $9 \times 9$ karena pixel citra yang digunakan cukup besar yaitu $200 \times 200$. Dalam penelitian ini tidak digunakan filter lolos rendah atau filter lolos tinggi dikarenakan dalam penelitian ini tiap-tiap frekuensi atau nilai intensitas masih digunakan sebagai parameter pembeda masing-masing kualitas. Tampilan hasil filterisasi diperlihatkan pada Gambar 6 .

\section{Ekualisasi}

Proses ekualisasi bertujuan untuk memperoleh penyebaran tingkat intensitas yang merata sedemikian rupa sehingga setiap tingkat intensitas memiliki jumlah pixel yang relatif sama. Prosedur ekualisasi adalah mengubah tingkat intensitas suatu pixel (r) dengan tingkat intensitas yang baru (s) dengan suatu fungsi transformasi T. Berdasar data pada workspace tampak bahwa hasil ekualisasi R bernilai antara 120-150, ekualisasi G bernilai antara 90-120, dan ekualisasi B bernilai antara 20-70. Hasil ekualisasi citra latih ke 120 diperlihatkan pada Gambar 7.

\section{Ekstraksi Mean dan Standar Deviasi}

Ekstraksi fitur histogram yang dilakukan dalam penelitian ini adalah ekstraksi nilai rata-rata (mean) dan nilai penyimpangan (standar deviasi) tiap-tiap nilai indeks RGB, sehingga didapatkan 3 nilai untuk mean dan 3 nilai untuk standar deviasi untuk masing-masing citra. Nilai-nilai tersebut didapatkan dari toolbox Matlab. Nilai mean menunjukkan nilai intensitas rata-rata tiap indeks warna RGB. Sedangkan nilai standar deviasi menunjukkan penyimpangan maksimum dari nilai intensitas rata-rata tiap indeks warna RGB. Tabel III memperlihatkan beberapa nilai mean dan standar deviasi untuk tiap-tiap kualitas biji jagung.

Tampak dari Tabel III bahwa nilai mean mayoritas adalah tinggi $(>60)$, sedangkan nilai standar deviasi bernilai rendah $(<40)$. Pada indeks warna Red kebanyakan memiliki nilai mean tinggi dan nilai standar deviasi yang rendah. Sedangkan
TABEL III: Nilai mean dan standar deviasi dari setiap kualitas biji jagung (citra ke-1, ke-31, ke-61, dan ke-91).

\begin{tabular}{cccccc}
\hline \hline \multicolumn{1}{c}{ F I T U R } & Busuk & Berjamur & Normal & Rusak \\
\hline \multirow{2}{*}{ Mean Ged } & 99.4015 & 106.112 & 159.245 & 146.991 \\
& Green & 91.5701 & 97.6426 & 116.985 & 130.981 \\
& Blue & 82.4024 & 65.6267 & 61.6174 & 92.1114 \\
\hline \multirow{3}{*}{ Sd } & Red & 31.6285 & 25.8861 & 9.64993 & 24.9429 \\
& Green & 32.5234 & 25.3534 & 11.3483 & 25.2972 \\
& Blue & 32.8945 & 23.7717 & 15.4406 & 28.9410 \\
\hline \hline
\end{tabular}

kebalikannya, pada indeks warna Blue, kebanyakan memiliki nilai mean rendah dan nilai standar deviasi yang tinggi. Keenam nilai ini yang nantinya dijadikan sebagai parameter dalam mengklasifikasikan citra ke dalam beberapa kualitas biji jagung.

\section{Pelatihan dan Pengujian Jaringan}

Setelah semua citra biji jagung telah terekstraksi fitur histogramnya, langkah berikutnya adalah proses pelatihan dan pengujian menggunakan Jaringan Syaraf Tiruan yang termasuk jaringan dengan pelatihan terawasi (supervised). Proses pelatihan bertujuan untuk melatih sistem dalam mengenali citra serta untuk mendapatkan bobot. Bobot ini yang akan digunakan sebagai masukan dalam proses pengujian. Untuk bobot awal terdiri dari bobot awal input, bobot awal bias input, bobot awal lapisan dan bobot awal bias lapisan. Dalam proses pelatihan, kita sudah menentukan terlebih dahulu nilai output untuk tiap kualitas. Dikarenakan fungsi aktivasi yang digunakan adalah fungsi aktivasi logsig (fungsi yang membawa nilai input menuju output dengan rumus log-sigmoid), dimana nilai outputnya adalah 0 dan 1 , maka berikut ini adalah nilai output yang kita tentukan untuk masing-masing kualitas (Tabel IV).

Kriteria bobot terbaik adalah bobot yang memiliki tingkat akurasi tinggi (mendekati 100\%) dan eror yang rendah (mendekati 0\%). Untuk mendapatkan bobot terbaik ini, bisa 
TABEL IV: Nilai output dari tiap kualitas.

\begin{tabular}{lllll}
\hline \hline Kualitas & \multicolumn{2}{l}{ Output } \\
\hline Busuk & 1 & 0 & 0 & 0 \\
Berjamur & 0 & 1 & 0 & 0 \\
Normal & 0 & 0 & 1 & 0 \\
Rusak & 0 & 0 & 0 & 1 \\
\hline \hline
\end{tabular}

TABEL V: Hasil pelatihan jaringan.

\begin{tabular}{lccccccc}
\hline \hline Citra & Jml & \multicolumn{2}{c}{ Terdeteksi } & \multicolumn{2}{c}{ Sebagai } & \multicolumn{2}{c}{ Tingkat Eror } \\
Latih & Citra & B & J & N & R & Akurasi \\
\hline B & 30 & 30 & 0 & 0 & 0 & $100 \%$ & $0 \%$ \\
J & 30 & 0 & 30 & 0 & 0 & $100 \%$ & $0 \%$ \\
$\mathrm{~N}$ & 30 & 0 & 0 & 30 & 0 & $100 \%$ & $0 \%$ \\
$\mathrm{R}$ & 30 & 0 & 0 & 0 & 30 & $100 \%$ & $0 \%$ \\
\hline Jml & 120 & Prosen & tase & Rata- Rata & $100 \%$ & $0 \%$ \\
\hline \hline
\end{tabular}

dilakukan dengan mengubah beberapa parameter, seperti jumlah neuron, jumlah layer, atau jumlah iterasi. Perubahan tingkat akurasi tersebut disebabkan karena bobot awal input, bobot awal bias input, bobot awal lapisan dan bobot awal bias lapisan diatur untuk terisi secara acak. Sehingga tidak selamanya jumlah neuron, layer, dan iterasi yang banyak mampu menghasilkan bobot yang baik. Setelah dilakukan beberapa kali percobaan, didapatkan bobot sempurna, yaitu akurasi $100 \%$ dan eror $0 \%$ (Tabel V) dengan menggunakan parameteparameter berikut:

- Hidden Layer $=4$

- Output Layer $=4$

- Neuron $=500$

- Iterasi $=1500$

- Laju Pembelajaran $=0,01$

Laju pembelajaran berfungsi sebagai pengali bobot ketika akan dilakukan iterasi ulang dan juga sebagai pengatur kecepatan proses pelatihan.
Hasil proses pengujian dapat dilihat pada Tabel VI. Tampak bahwa biji busuk memiliki tingkat akurasi paling rendah. Hal ini disebabkan karena citra biji busuk memiliki kemiripan dengan citra biji berjamur. Ternyata setelah dilakukan pengujian, hanya setengah citra biji busuk yang sesuai dengan harapan. Setengahnya terdeteksi sebagai biji berjamur. Sedangkan satu citra terdeteksi sebagai biji rusak, bahkan ada 1 data yang

TABEL VI: Hasil pengujian jaringan.

\begin{tabular}{cccccccc}
\hline \hline Citra & Jml & \multicolumn{2}{c}{ Terdeteksi } & \multicolumn{2}{c}{ Sebagai } & Tingkat & Eror \\
Latih & Citra & B & J & N & R & Akurasi & \\
\hline B & 20 & 9 & 9 & 0 & 1 & $45 \%$ & $55 \%$ \\
J & 20 & 3 & 15 & 0 & 2 & $75 \%$ & $25 \%$ \\
N & 20 & 0 & 0 & 18 & 2 & $90 \%$ & $10 \%$ \\
R & 20 & 0 & 1 & 0 & 17 & $85 \%$ & $15 \%$ \\
\hline Jml & 80 & \multicolumn{7}{l}{ Prosen tase } & Rata- Rata & $73,75 \%$ & $26,25 \%$ \\
\hline
\end{tabular}

tidak dikenali. Dalam pengujian ini, yang memiliki tingkat akurasi paling tinggi adalah biji normal. Hal tersebut karena citra biji normal memiliki perbedaan yang sangat mencolok dibandingkan dengan citra biji jagung yang lain. Warnanya sangat kuning mencolok dengan persebaran yang merata serta permukaannya halus.

\section{SIMPULAN}

Beberapa hal yang dapat disimpulkan dari penelitian ini adalah: Proses pengklasifikasikan biji jagung ke dalam 4 macam kualitas (biji busuk, biji berjamur, biji normal, dan biji rusak) dapat dilakukan dengan menggunakan Jaringan Syaraf Tiruan metode backpropagation serta ekstraksi indeks warna RGB, mean, dan standar deviasi pada citra digitalnya. Akurasi dari metode Jaringan Syaraf tiruan yang telah dibuat memberikan performansi sebesar $100 \%$ untuk proses pelatihan dan sebesar $73,75 \%$ untuk proses pengujian dengan menggunakan 1500 iterasi, 500 neuron, 4 hidden layer dan 0,01 learning rate.
[1] H.K. Purwadaria, Teknologi Penanganan Pascapanen Jagung (Deptan-FAO, UNDP, 2007).

[2] A.S. Somantri, Mengidentifikasi Mutu Fisik Jagung dengan Memanfaatkan Teknologi Pengolahan Citra Digital.

[3] M.A. Bustomi, H. Bisri dan E. Purwanti, Jurnal Fisika dan Aplikasinya, 10(1) 19-23 (2014).

[4] S. Kusumadewi, Artificial Intelligence, Teknik dan Aplikasinya (Graha Ilmu, Yogyakarta, 2003)

[5] Z. Li, L. Zhao, and N.Y. Soma, Fractal Color Image Compres- sion. Proceedings of XIII Brazilian Symposium on Computer Graphics and Image Processing ( Gramado (RS), Brazil, October 17-20, 2000).

[6] A.M. Arymurthy, dan S. Suryana, Pengantar Pengolahan Citra ( PT. Elex Media Komputindo, Jakarta, 1992 )

[7] D. Putera, Pengolahan Citra Digital ( Andi Publisher, Yogyakarta, 2010). 